Ann. Biol. anim. Bioch. Biophys., 1977, 17 (2), 173-178.

\title{
Developmental aspects of bursa of Fabricius and thymus during post-hatching ontogenesis in Gallus domesticus
}

par Rodica GIURGEA

Centrul de cercetari biologice, Strada Clinicilor 5-7

3400 Cluj, Roumania

Summary. The bursa of Fabricius reaches its maximum weight at 49 days after posthatching ; thymus weight increases continually af a higher rate than the bursa until at least 126 days. Involution of the bursa is gradual ; by 525 days it is a fluid-filled vesicle. The biochemical parameters investigated (DNA, RNA, total protein and aminoacid nitrogen content) vary more in the thymus than in the bursa during this age-period. The differences observed between these two glands explain the role they play in the lympho-reticuloendothelial system.

\section{Introduction.}

The bursa of Fabricius and the thymus are central lymphatic organs in bird ; their activity depends on the developmental stage of the animal (Grennwood, 1929 ; Jolly, 1913 ; Payne, 1971) has shown that their surgical removal causes age-dependent changes. There are some data in the literature on biochemical (Kemeny et al., 1968 ; Pora et al., 1962 ; Stefoni ef al., 1971) and weight (Klima, 1957) changes in the bursa of Fabricius and the thymus during posthatching ontogenesis.

The immunological role of these two bird glands is not known. In the present investigation we studied the development of protein metabolism in normal chicks during posthatching ontogenesis.

\section{Material and methods.}

Tetralinear hybrid Studler-Cornish chicks and fowl were studied over a 4-month period (January to April) beginning at hatching. Groups of 8-10 chicks were killed by decapitation at days $1,3,5,6,8,10,11,16,19,23,26,28,33,35,38,43,49,60,77,126$ of posthatching. The thymus and bursa of Fabricius were weighed on a torsion scale and the amounts of the following components were determined : total proteins (TP) ( $\mathrm{mg} / 100 \mathrm{mg}$ ) by the method of Robinson and Hogben modified by Korpaczy (Kovách, 1958), RNA and DNA (mg/g) by the Spirin method (1958), free aminoacid nitrogen 
(mg/100 g) by the Rác procedure (1959). Values were expressed in fresh tissue weight. The clear yellowish fluid found in the adult fowl ( 525 days old) vesicle, which developed from the chick bursa of Fabricius, was used to determine total proteins by the method of Wolfson ef al. (1948) and free aminoacid nitrogen by the method of Rác (1959). The same parameters were determined in the serum by blood clotting.

Standard error of the mean was calculated after eliminating aberrant results according to Chauvenet's criterium. Student's procedure was used for statistical checking.

\section{Results and discussion.}

Mean biochemical values obtained are given in figures 1 and 2 ; organ and body weight changes are shown in Figure 3 . Three periods are distinguished : the first, up to about day 5 posthatching $(A)$; the second, up to about 3 months posthatching $(B)$; the third after this age (C).

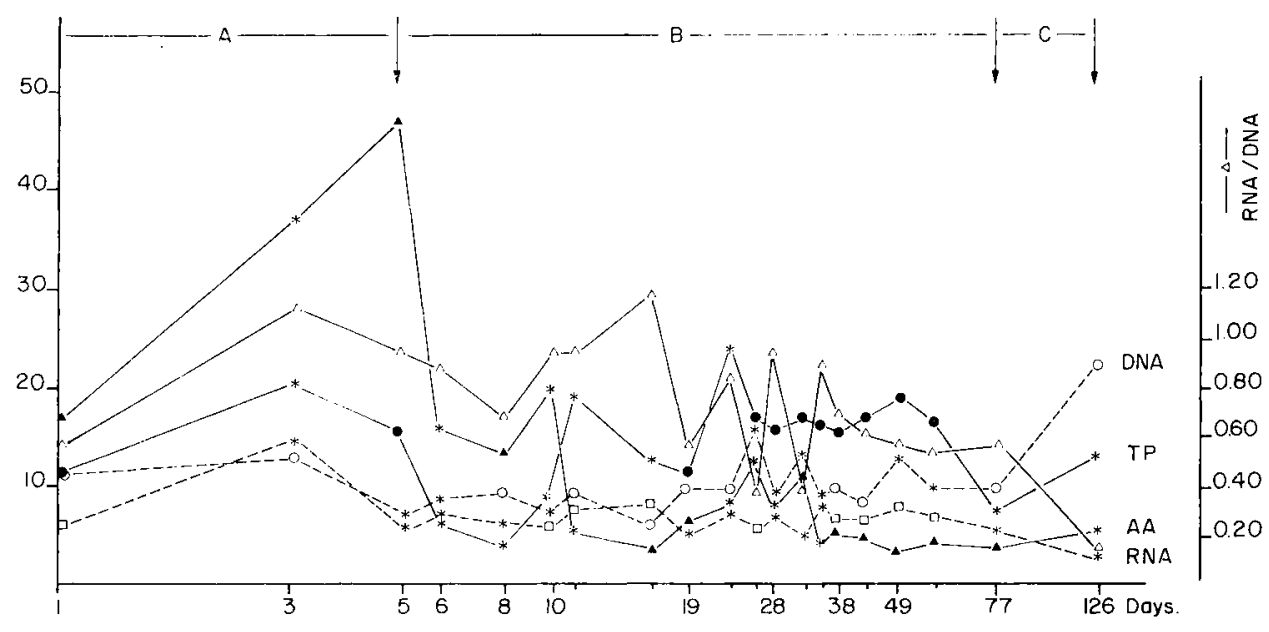

FIG. 1. - Age-dependent variation of protein (TP), DNA, RNA and total free aminoacid (AA) concentration in bursa of fabricius during posthatching ontogenesis of chicken (time in logarithmic scale).

Statistically significant differences $(p<0.05)$ between two adjacent ages are evidenced on the curves by $*$ at the second age. Values on the ordinate are : $\mathrm{mg} / 100 \mathrm{mg}$ for TP, $\mathrm{mg} / \mathrm{g}$ for DNA and RNA, and $\mathrm{mg} / 100 \mathrm{~g}$ for $\mathrm{AA}$.

Period $A$ is characterized by constant weight of thymus and bursa and increasing TP, RNA, DNA and aminoacid concentrations. During period B the weight of the two glands, and especially that of the thymus, increases. Biochemical parameters vary but TP tends to increase. In period $C$, thymus weight increases further, but that of the bursa of Fabricius decreases. Other values also vary in opposite ways in the two glands : bursa of Fabricius weight augments while that of the thymus decreases. Only DNA concentration increases in both glands. 
The standard error expressed as a percentage of the means shows that variability is higher in 1-19 day-old chickens than in older ones, and in the thymus than in the bursa of Fabricius. There are thus differences in the ontogenetical development of the two glands. These variations were reported by other authors (Glick, 1956 ; Klima, 1957 ; Stefoni ef al., 1971).

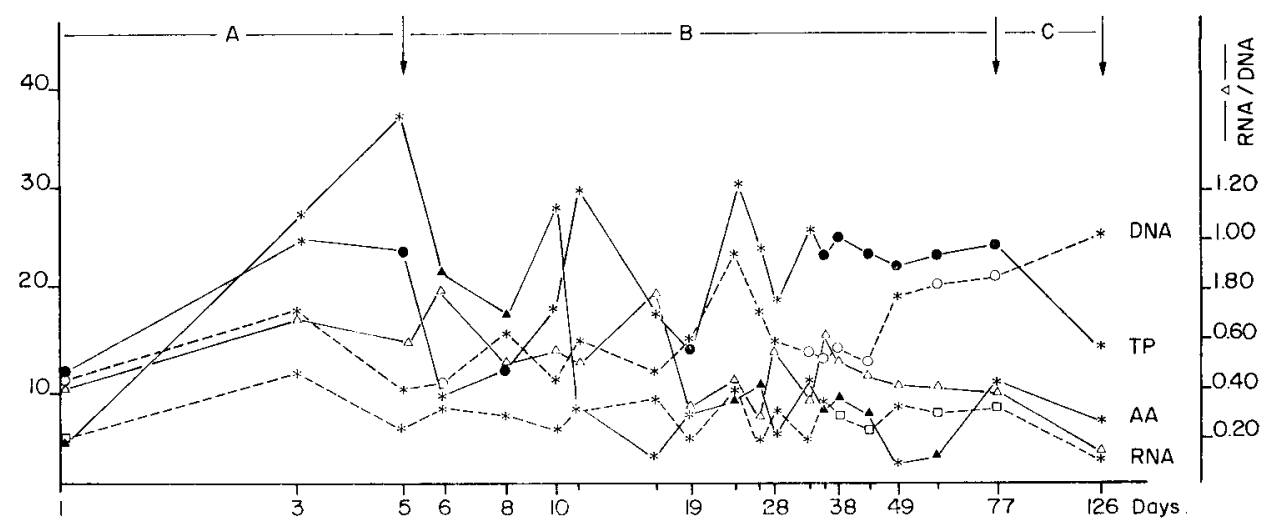

FIG. 2. - Age-dependehnt variation of protein (TP), DNA, RNA and total free aminoacid (AA) concentration in thymus during posthatching ontogenesis of chicken (time in logarithmic scale).

Statistically significant differences $(P<0.05$ ) between two adjacent ages are evidenced on the curves by * at the second age. Values on the ordinate are : $\mathrm{mg} / 100 \mathrm{mg}$ for TP, $\mathrm{mg} / \mathrm{g}$ for DNA and RNA and $\mathrm{mg} / 100 \mathrm{~g}$ for $\mathrm{AA}$.

Although the bursa of Fabricius and the thymus have been found similar in structure and function in an immunological study (Pozsgi and Ghyka, 1974), they differ in ontogenetical evolution because the bursa of Fabricius is implicated in humoral immunity, while the thymus plays a rôle in cellular immunity (Payne, 1971 ; Pozsgi and Ghyka, 1974). These organs are not well-developed in the newly-hatched chick. The thymus, however, is the heavier of the two although it is poorly individualized, its lobes being embedded in a large amount of fat.

Our present and past (Wittenberger et al., 1976) data show that the glands have different growth patterns ; the bursa of Fabricius lags behind the thymus. This observation does not agree with the findings of Klima (1957). Our present and our past (Wittenberger ef al., 1976) data do not agree either on thymus involution. Previously we showed the beginning of thymus involution by 5 weeks posthatching; our present observations show no involution until at least 4 months. The experiments of the work cited above being carried out in August-October, seasonal effect at the time of observation or the conditions in which the animals were raised may play a role. Both glands are sensitive to these environmental factors (Glick, 1956 ; Klima, 1957 ; Pintea ef al., 1964).

Klima (1957) noted maximal thymus weight at 28 days and Payne (1971) showed that by 35 days bursa of Fabricius weight surpassed thymus weight and then reached a plateau. In agreement with Klima (1957), we also found that the bursa of Fabricius shows an earlier involution than the thymus ; were detected involution in the former 
gland by 7 weeks (fig. 3). This may be related to the higher sensitivity of that gland to glycocorticosteroid hormones. Bursa of Fabricius involution leads to the development of a fluid-filled vesicle in the adult fowl. The protein and aminoacid content of this fluid is much lower than in blood serum (table 1 ).

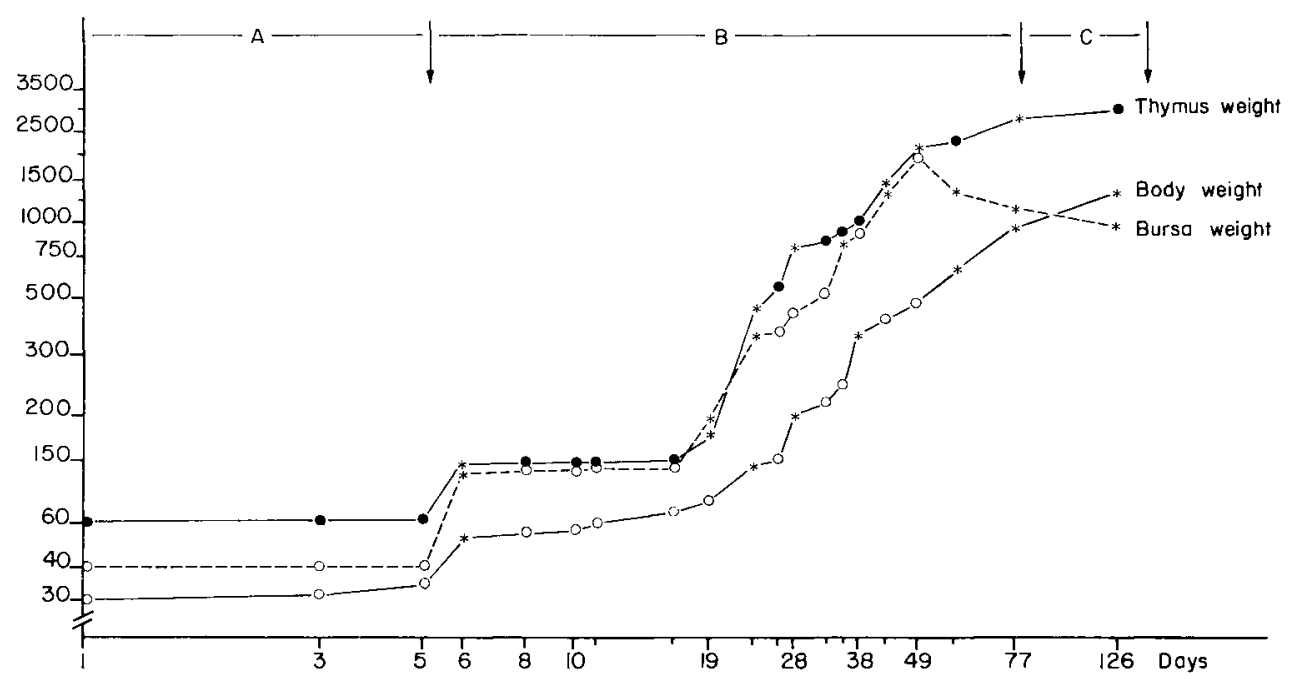

FIG. 3. - Variation of body weight and of bursa of Fabricius and thymus weight during posthatching ontogenesis of chicken (values on logarithmic scale on both abscissa and ordinate).

Mean values are given in grams for body weight, in milligrams for organ weight.

According to Glick (1956), the weight of the bursa of Fabricius increases considerably during the first three posthatching weeks, reaches a plateau and finally drops. The period of rapid growth may correspond to a low steroid hormone level, not affecting the bursa of Fabricius. In out chickens involution of the bursa of Fabricius occurred later ; the thymus did not show involution at all during our study. This is

\section{TABLE 1}

Total protein and total free aminoacid content of the bursal vesicle and of the blood serum in 525-days fowl

\begin{tabular}{|c|c|c|}
\hline & $\begin{array}{l}\text { Protein } \\
\text { (g. p. 100) }\end{array}$ & $\begin{array}{l}\text { Total free aminoacid } \\
(\mathrm{mg} / 100 \mathrm{~g})\end{array}$ \\
\hline Blood serum .... & $6.93 \pm 0.49(8)$ & $2.73 \pm 0.23(9)$ \\
\hline Bursal vesicle ... & $2.17 \pm 0.34(8)$ & $1.32 \pm 0.17(8)$ \\
\hline$R \ldots \ldots \ldots \ldots$ & 0.313 & 0.484 \\
\hline
\end{tabular}

Values are given as means \pm standard errors; the number of individuals is shown in parentheses; $R$ represents the ratio of protein and aminoacid concentration in the vesicle fluid to that of the blood serum. 
difficult to understand in view of the time of hypothalamus-hypophyseal-adrenal axis maturation (about 3 weeks) (Nvota et al., 1973) and the high sensitivity of both glands to glycocorticosteroid hormone action. Indeed, specific receptors for these hormones have been found in the nucleus and the cytoplasm of the thymic lymph cells (Abraham, 1975).

Aminoacids may decrease after day 5 of posthatching because they may be used in the synthesis of $\lg G$ (which increases in concentration) and of $\lg M$, lacking in the blood of chickens at hatching (Morgan ans Glick, 1972). Grossi et al. (cited by Stefoni ef al., 1971) showed that during the first posthatching month gamma-G synthesis occurs in the bursa of Fabricius. According to Tsinovyj (1967), immunological maturity is achieved by 13 weeks the gamma-G concentration reaches its adult value ; Cho (1963) found this at 6 weeks.

DNA decrease on day 5 (also observed by Stefoni ef al., 1971) was not accompanied in our chickens by increased protein, as reported by the above authors. This decrease is explained by Prochazka ef al. (1976) as the expression of low bursal lymphocyte mitotic activity; it is accompanied by RNA decrease in both the bursa of Fabricius and the thymus due to lymphocyte rearrangement. RNA content at hatching was low in the bursa of Fabricius in our chickens, and even lower in the thymus; it sharply increased at day 3 (especially in the bursa), then decreased at day 5 and remained almost unchanged during our study. The RNA/DNA ratio decreases due to increased DNA concentration. We cannot explain this observation.

In conclusion, both the bursa of Fabricius and the thymus show the same general modifications, differing especially in the last ontogenetical stage studied.

Accepté en seplembre 1976.

Résumé. On a étudié le développement de la bourse de Fabricius et du thymus chez des poulets Studler-Cornish, de l'éclosion à l'âge de 126 jours. On a suivi des indices pondéraux (poids des deux organes et poids corporel) et métaboliques (ARN, ADN, protéines totales, acides aminés libres).

Durant les 7 premières semaines, les trois indices pondéraux augmentent (le poids de la bourse plus lentement). A 49 jours après l'éclosion, le poids de la bourse atteint son maximum et l'involution commence. A 126 jours, le développement du thymus n'est pas terminé.

Les contenus en protéines, ADN et ARN diminuent dès le $5 \mathrm{e}$ jour. La diminution est plus accentuée pour la bourse. Durant toute la période suivante, les variations du contenu en protéines sont accompagnées de variations en sens inverse du contenu en acides aminés libres.

Chez les poules en pontes, la bourse est remplacée par une vésicule remplie d'un liquide dont la concentration en protéines et aminoacides est plus basse que celle du sérum sanguin.

En conclusion, l'évolution des deux glandes au cours du développement est comparable, mais pas identique. Pendant toute la durée de l'étude, les indices suivis ont montré une grande variabilité. 


\section{References}

ABRAHAM A. D., 1975. Action mechanism of steroid hormones (in Romanian), Ed. Acad. RSR, Bucuresti, 74-94.

CHO B.-R., 1963. The effect of bursectomy of chickens in antibody response to newcastle disease virus. Am. J. Vet. Res., 24, 832-834.

GLICK B., 1956. Normal growth of the bursa of Fabricius in chickens. Poult. Sci., 35, 843-850.

GRENNWOOD A. W., 1929. Some observation on the thymus gland in the fowls. Proc. Roy. Soc. Edimb., 50, 26-37.

JOLLY J., 1913. L'involution physiologique de la bourse de Fabricius et ses relations avec l'apparition de la maturité sexuelle. C. R. Soc. Biol., 75, 638-648.

KEMENY V., PETHES G., KOZMA M., 1968. Chromatographically separable fractions in the extract of bursa of Fabricius in the chicken. Comp. Bioch. Physiol., 26, 757-758.

KLIMA M., 1957. Entwicklungsverlauf der Bursa Fabricii (in Czech.). Acta Soc. Zool. Bohemoslov. 21, 332-354.

KOVACH A., 1958. Investigation methods of experimental medicine (in Hungarian), Akad. Kiado Budapest, Pp. 28.

MORGAN W., GLICK B., 1972. A quantitative study of serum proteins in bursectomized and irradiated chickens. Poult. Sci., 51, 771-778.

NVOTA J., LAMOSOVA D., FABEROVA A., 1973. Critical periods in the development of chicks. Physiol. Bohemoslov., 22, 337-343.

PAYNE L. N., 1971. The lymphoid system, in BELL D. J. and FREEMAN B. M., Physiology and biochemistry of the domestic fowl, 2, 985-1037, Acad. Press, London and New York.

PINTEA V., NETEDU N., JIVANESCU I., GARICI I., 1964. Effects of bursectomy in chickens (in Romanian), Morfol. norm. patol., 9, 63-69.

PORA A. E., TOMA V., ABRAHAM A. D., 1962. Evolution des acides aminés libres dans le thymus ef dans la bourse de Fabricius pendant l'ontogenèse chez le poulet. C. R. Acad. Sci. Paris, 255, 2010-2011.

POZSGI N., GHYKA G., 1974. Immunogenetics (in Romanian), Ed. Acad. RSR, Bucuresti.

PROCHAZKA Z. D., RODAK L., KTEJEI J., 1967. On the role of the bursa of Fabricius in ontogenetic development of chickens. Acta Vet. Hung., 17, 223-230.

RAC I., 1959. Determination of total free aminoacids by ninhydrine. Cas. likarum., 98, 120-123.

SPIRIN A. S., 1958. Spectrophotometric determination of total nucleic acids (in Russian), Biokhimia, 23, 656-662.

STEFONI S., GROSSI C. E., MANZOLI F. A., MANZOLI L., 1971. Investigation on the developing chicken bursa of Fabricius. Poult. Sci., 50, 1701-1705.

TSINOVYJ V.1., 1967. Protein complexes of the blood in chicken embryos and chickens (in russian) in Fiziologia ptits (Physiology of the birds), 31-35, Valgus, Tallin.

WITTENBERGER C., MADAR I., GIURGEA R., SUTEU D., CHIS L., COPREAN D., ILONCA A., 1976. Changes in some ponderal and metabolic parameters in chicks aged one to three months. Ann. Biol. anim. Bioch. Biophys., 16, 101-106.

WOLFSON W. Q., COHN C., CALVARY E., ICHBA F., 1948. Studies in serum proteins. V. A. rapid procedure for the estimation of total protein, true albumin, total globulin, alpha globulin, beta globulin and gamma globulin in 1. 0. $\mathrm{ml}$ of serum. Amer. J. Clin. Pathol., 18, 723-725. 